\title{
Lucilia sericata'nın Lusifensin, Kimotripsin Proteinleri ve Moleküler Karakterizasyonları
}

\author{
Lucifensin, Chymotrypsin Proteins and Molecular \\ Characterization of Lucilia sericata
}

\author{
Emrah ERDOĞAN ${ }^{1}\left(\right.$ ID), Serkan KARACA ${ }^{1}$ (ID) \\ ${ }^{1}$ Erciyes Üniversitesi Tıp Fakültesi, Tıbbi Parazitoloji Anabilim Dalı, Kayseri. \\ ${ }^{1}$ Erciyes University Faculty of Medicine, Department of Medical Parasitology, Kayseri, Turkey.
}

Makale Atıfı: Erdoğan E, Karaca S. Lucilia sericata'nın lusifensin, kimotripsin proteinleri ve moleküler karakterizasyonları. Mikrobiyol Bul 2021;55(1):81-90.

\section{ÖZ}

Calliphoridae familyasının en yaygın türlerinden biri olan Lucilia sericata, dışkı, çöp ve leşlerin çevresinde çok sayıda bulunmaktadır. Bu sinek türü tıpta, adli tıpta ve veteriner hekimlikte önemlidir. Parazitin larvaları, hayvansal üretimde önemli kayıplara yol açtıkları için hem veteriner hekimlikte hem de hayvansal hastalıklarla mücadelede önemlidir. Cesetlere yerleşen ilk sinek kolonilerinden biri oldukları için adli tıp alanında ölüm zamanının belirlenmesinde de kullanılabilmektedirler. Sinek larvaları ile tedavi yöntemi olan Maggot debritman tedavisi (MDT)'nde kullanılan L.sericata larvaları, yaralarda nekrotik dokuları ve enfeksiyon etkenlerini yok ederek yara iyileşmesine yardımcı olur. Larvalar salgıladıkları proteinler ile polimikrobiyal floradan korunurken; aynı zamanda salgılanan bu moleküller ile yara iyileşmesine ilginç bir katkı sağlarlar. Son yıllarda keşfedilen bu moleküllerin en önemlilerinden biri antifungal etkiye sahip olan lusimisindir. Ayrıca lusifensin ve kimotripsin salgıları, antibakteriyel etkileri ve özellikle dirençli gram-negatif ve pozitif bakteriler üzerindeki etkileri nedeniyle son yıllarda önem kazanmıştır. İyileşmeyen yaraların tedavisinde alternatif olabilecek veya mevcut antibiyotikler ile beraber uygulanması mümkün olan moleküllerin keşfine ihtiyaç duyulmaktadır. Kurtçuk tedavisinde yer alan bileşiklerin antimikrobiyal karakterizasyonunu ve mekanizmalarını gösteren çaış̧malara intiyaç bulunmaktadır. Bu çalışmada, MDT'nde kullanılan L.sericata larvalarının salgıladığı önemli defensin moleküllerinden olan lusifensin ve kimotripsin genlerinin; klonlanmaları, moleküler karakterizasyonları ve antijenik yapılarının analizi amaçlanmışır. Öncelikle moleküler çalışmalarda kullanılmak üzere L.sericata kolonileri yetiştirilmiştir. Daha sonra larvalardan RNA izolasyonu ve CDNA sentezi gerçekleştirilmiştir. Lusifensin ve kimotripsin genleri, klonlama reaksiyonları ile pJet1.2 plazmidine ayrı ayrı yerleştirilmiştir. Rekombinant plazmidin varlığı, tüm aşamalarda polimeraz zincir reaksiyonu (MDT) taraması ve DNA dizi analizi yöntemleriyle doğrulanmıştır. Yara tedavisinde önemli larval bileşenlerden olan bu iki genin nükleotit ve amino asit tabanlı moleküler karakterizasyonları yapılmıştır. Proteinlerin antijenik bölgeleri ve üç boyutlu yapıları elde edilmiştir. L.sericata lusifensin geninin MT495795 numaralı ve kimotripsin geninin MT495794 numaralı izolatlarının kayıtları GenBank'a yapılmışır. Türkiye Cumhuriyeti'nden ilk kez bildirilen bu veriler ile literatüre katkı sağlanacaktır. Yirminci yüzyılın başlarından antibiyotiklerin keşfedilmesine kadar geçen sürede özellikle askerler üzerinde etkili bir şeklide uygulanan MDT, antibiyotiklerin keşfinden sonra fazla uygulama alanı bulamamıştır. Günümüzde yara tedavilerinde karşılaşılan en önemli sorun olan ilaç direnci, MDT'nin ve etki mekanizmalarının hatırlanmasına neden olmuştur. Bu çalışmada, yara tedavilerinde önemli Melikgazi 38039, Kayseri, Türkiye. Tel (Phone): +90 35220766 66, E-posta (E-mail): emrah@erciyes.edu.tr 
moleküllerin keşfi ve uygulanabilirliği konusunda farklı alanlardan bilim insanlarının multidisipliner çalışmalarına kaynak oluşturacak veriler elde edilmiştir.

Anahtar kelimeler: Lucilia sericata; maggot debritman tedavisi; lusifensin; kimotripsin; moleküler karakterizasyon.

\section{ABSTRACT}

Lucilia sericata, one of the most common species of the Calliphoridae family, is found in large numbers around droppings, garbage and carcasses. This fly species is important in medicine, forensics and veterinary medicine. The larvae of the parasite are important both in veterinary medicine and in combating of the animal diseases, as they cause significant losses in animal production. Since they are one of the first fly colonies to settle on corpses, they can also be used in determining the time of death in the field of forensic medicine. L.sericata larvae used in Maggot debridement treatment (MDT) which is a treatment method with fly larvae, help wound healing by destroying necrotic tissues and infectious agents in wounds. While the larvae protect themselves from polymicrobial flora with the proteins they secrete; at the same time, they make an interesting contribution to wound healing with these molecules secreted. One of the most important molecules discovered in recent years is lucimycin which has an antifungal effect. In addition, lucifensin and chymotrypsin secretions have gained importance in recent years due to their antibacterial effects and especially their effects on resistant gram-negative and positive bacteria. There is a need for the discovery of the molecules that can be alternative in the treatment of non-healing wounds or that can be applied together with existing antibiotics. It is necessary to investigate the antimicrobial characterization of the compounds involved in maggot therapy and their mechanisms. The aim of this study was to clone, molecular characterization and analysis of the antigenic structures of lucifensin and chymotrypsin genes, which are important defensin molecules secreted by L.sericata larvae used in MDT. Primarily, the cultivation of L.sericata colonies to be used in molecular studies were performed. Later, RNA isolation and CDNA synthesis from larvae were carried out. Lucifensin and chymotrypsin genes were individually inserted into the pJet1.2 plasmid by cloning reactions. The presence of the recombinant plasmid was confirmed by PCR screening and DNA sequence analysis methods in all steps. Nucleotide and amino acid based molecular characterizations of these two genes, which are important larval components in wound treatment, have been made. Antigenic regions and three-dimensional structures of the proteins were obtained. The isolate numbered MT495795 of the L.sericata lucifensin gene and the isolate numbered MT495794 of the chymotrypsin gene were registered to GenBank. This data reported for the first time in the Republic of Turkey will contribute to the literature. From the beginning of the $20^{\text {th }}$ century until the discovery of the antibiotics, MDT was applied especially on soldiers but did not find much application area after the discovery of the antibiotics. Drug resistance, which is the most important problem encountered in the treatment of the wounds today, has led to the recall of MDT and its mechanism of action. In this study the data, obtained will constitute a source for the multidisciplinary studies of the scientists from different fields on the discovery and applicability of the important molecules in the treatment of the wounds.

Keywords: Lucilia sericata; maggot debridement therapy; lucifensin; chymotrypsin; molecular characterization.

\section{Giriş̧}

Lucilia sericata; erişkini yeşil mavimsi metalik renklerde 5-10 mm büyüklükte olan sinek türlerindendir. Vücudun ön bölümünde kılların uzunluğu ile karın bölümünde bulunan kılların uzunlukları aynıdır ${ }^{1}$. Birçok artropod türünde olduğu gibi mezotoraks üzerindeki kıllar tür tayininde önemlidir. Bacak ve baş parçaları siyah, kanatlar kiremit rengindedir. Dişiler yumurtalarını toplu şekilde yumurtlar. Yumurta renkleri sarımsı krem rengindedir. Bu tür, dünyanın hemen hemen her bölgesinde görülebilmektedir. Güney Yarım Küre'de daha sık görülmekle birlikte, özellikle Amerika kıtasının nemli kıyı kesimlerini tercih eder². 
Kurtçukların yara tedavisinde faydalı olduğunu görerek ilk yazılı kaynakları kaleme alan Fransız Doktor Ambroise Pare olmuştur. Napolyon'un birliklerinde doktorluk yapan Baron Larrey'in ve Amerika'da iç savaş yıllarında hekim olan Joseph Jones'in askeri birlikler içerisinde yaptığı çalışmalarda ${ }^{3,4}$, larvaların sadece ölü dokuyu yedikleri ve canlı dokulara dokunmadıkları sonucu ortaya çıkmıştır. Larvaların antimikrobiyal kontamine bir ortama (yara bölgesi gibi) yerleştirilmesinin, larvada antimikrobiyal faktörlerin üretilmesine ve bu faktörlerin dışarıya da salgılanmasına yol açtığı düşünülmektedir ${ }^{5}$. Maggot debritman tedavisi (MDT), penisilin ve sülfonamitlerin bulunmasıyla tamamen unutulmuş; özellikle son 30 yılda karşılaşılan antibiyotik direnci sonucunda tekrar hatırlanmıştır. Yirminci yüzyılın son yıllarında kurulan Uluslararası Biyoterapi Topluluğu; geçmeyen kronik yaraların tedavisinde kullanılan, kurtçuk ve salgılarının incelenmesi, geliştirilmesi üzerine çalışmalar yapmaktadır ${ }^{6,7}$.

Çalışmada, MDT'nde kullanılan L.sericata larvalarının salgıladığı önemli defensin moleküllerinden olan lusifensin ve kimotripsin genlerinin klonlanmaları, moleküler karakterizasyonları ve antijenik yapılarının analizi amaçlanmıştır.

\section{GEREÇ ve YÖNTEM}

\section{Lucilia sericata Kolonisi ve İnsektaryum Koşulları}

Çalışma, Erciyes Üniversitesi Tıp Fakültesi Tıbbi Parazitoloji Anabilim Dalında bulunan insektaryum ünitesinde gerçekleştirildi. Yaşam formlarının sağlıklı bir şekilde takipleri insektaryum koşullarında yapıldı. Laboratuvar ortamında yetiştirilen parazit erişkinleri için optimum insektaryum koşulları sağlandı.

\section{Lucilia sericata Larvalarından RNA İzolasyonu}

İkinci dönem larvalardan RNA izolasyonu, Trigent RNA İsolation Reagent (Biomatik/ K5161-1×100 ml) kiti kullanılarak yapıldı. Larvalar mikrosantrifüj tüp içerisine konularak bir kürdan yardımıyla parçalandı. Kit prosedürü takip edilerek işlem tamamlandı.

\section{cDNA Sentezlenmesi}

"Transcriptor high fidelity cDNA synthesis (Roche, Almanya)" kiti kullanıldı. Total RNA'lardan (1 pg veya $1 \mu \mathrm{g}$ ) 1 H PCR tüplerine eklendi. Kit prosedürü takip edilerek işlem tamamlandı.

\section{Lusifensin, Kimotripsin Genleri ve Polimeraz Zincir Reaksiyonu}

Lucilia sericata lusifensin ve kimotripsin gen bölgelerine özgül primer çiftleri tasarlandı. Lusifensin geni için HM243535 GenBank numaralı gen dizisi ve kimotripsin geni için HV509835 GenBank numaralı gen dizisi referans alındı.

PCR karışımları iki gen bölgesi için; $12.5 \mu$ l karışımı (Takara, Japonya), $2 \mu$ l cDNA, 1 $\mu \mathrm{l} \mathrm{F}$ primeri (20 pmol) ve $1 \mu \mathrm{l}$ R primeri (20 pmol) ile beraber toplam $25 \mu$ l olacak şekilde hazırlandı. PCR amplifikasyonunda lusifensin geni için; $95^{\circ} \mathrm{C}^{\prime}$ de 10 dakika başlangıç denatürasyonunu takiben, toplam 35 döngü $95^{\circ} \mathrm{C}^{\prime}$ de 1 dakika denatürasyon, $53^{\circ} \mathrm{C}^{\prime}$ de 1 


\begin{tabular}{lc}
$\begin{array}{l}\text { Tablo I. Lusifensin ve Kimotripsin Gen Bölgelerinin Polimeraz Zincir Reaksiyonu Analizinde Kullanılan } \\
\text { Primerler }\end{array}$ & PCR ürün büyüklüğü \\
\hline Primer adı ve dizisi & 279 bp \\
\hline $\begin{array}{l}\text { L.s_Icfsn_F:5'-ATG AAA TTC TTT ATG GTA TTT GCC GT-3' } \\
\text { L.s_Icfsn_R:5'-TTA ATT ACG ACA CAC GCA AAT AGC T-3' }\end{array}$ & 225 bp \\
\hline $\begin{array}{l}\text { L.s_chymtrypsn_F:5'-GCT GCT CAC TGT ACC GAT GG-3' } \\
\text { L.s_chymtrypsn_R:5'-CTT GGG CAA AGT AGC AGG TTG-3' }\end{array}$
\end{tabular}

dakika primer bağlanması, $72^{\circ} \mathrm{C}^{\prime}$ de 1 dakika sentez olarak gerçekleştirildi. Son döngüyü takiben $72^{\circ} \mathrm{C}^{\prime}$ de 15 dakika son uzama işlemi yapıldı. Kimotripsin geni için primer bağlanması $55^{\circ} \mathrm{C}$ olacak şekilde aynı amplifikasyon programı kullanıldı. PCR ürünleri, etidyum bromür ile boyanan \%1.5'luk agaroz jelde yürütüldü ve "ChemiDoc Mp Imaging System (Bio-Rad, ABD)" cihazında görüntülendi.

\section{Lusifensin ve Kimotripsin Genlerinin pJet1.2 Plazmidine Klonlanmaları}

Klonlama reaksiyonlarında "CloneJET PCR Clonning Kit (Thermo Scientific, ABD)" kiti kullanıldı. Klonlama reaksiyonlarında; $10 \mu$ reaksiyon tamponu, $1 \mu$ l DNA "blunting" enzim, $1 \mu$ l PCR ürünlerinin bulunduğu $18 \mu \mathrm{l}$ karışım hazırlandı. Kit prosedürü takip edildi.

\section{Plazmitlerin Kompetan Hücrelere Transformasyonları ve Klonlamaların Doğrulanması}

Transformasyon işleminde "OneShot TOP10 Chemically Competent E.coli" hücreleri (Invitrogen, ABD) kullanıldı. $-80^{\circ} \mathrm{C}^{\prime}$ de bulunan OneShotTOP10 Chemically Competent E.coli kompetan hücreleri, buzun üzerine alınıp çözülmeleri beklendi. $3 \mu l^{\prime}$ lik ligasyon ürünleri, buzda bekleyen $100 \mu$ l OneShot TOP10 Chemically Competent E.coli hücrelerinin üzerine eklendi. Kit prosedürü takip edildi. Mikroplakların $37^{\circ} \mathrm{C}^{\prime}$ de bir gece inkübasyonu sonrası kontrolleri yapılarak, koloni oluşumları tespit edildi. İnkübasyonlar sonrası PCR tarama ve DNA dizi analizi yöntemleri ile koloni içerikleri rekombinant plazmit bulundurmaları yönünden doğrulandı.

\section{Lusifensin ve Kimotripsin Gen Dizileri, Filogenetik Analizleri ve Moleküler Karakterizasyonları}

Lusifensin ve kimotripsin genlerinin dizileri blastn (http://blast.ncbi.nlm.nih.gov/blast. cgi) analizlerinin sonrasında GenBank'a kayıtlı izolatlarla Geneious v.10.0.7 (Biomatters, $A B D$ ) programında çoklu hizalama tekniğiyle nükleotit benzerlikleri ve farkları incelendi.

\section{BULGULAR}

PCR sonrasında ürünler etidyum bromür ile boyanan \%1.5 agaroz jelde 100 baz çifti (bp)'lik belirteçle beraber (GeneAll Biotechnology, G. Kore) yürütülmüştür. Görüntüleme cihazında lusifensin geni 279 bp ve kimotripsin geni 225 bp büyüklüğünde görüntülenmiştir. 


\begin{tabular}{|lccccc|}
\hline \multicolumn{5}{|c|}{ Tablo II. L.sericata Kimotripsin Gen Dizisinin (MT495794) } & \multicolumn{4}{l|}{ GenBank'a } & Kayıtlı Dizilerle Karşılaştırılması \\
\hline Sıra No & Genbank ID & Organizma & Suş & Ülke & Benzerlik (\%) \\
\hline 1 & HV509835 & Lucilia sericata & - & Ingiltere & 99.55 \\
2 & XM_023437842 & Lucilia cuprina & - & Avustralya & 96.44 \\
3 & U07685 & Lucilia cuprina & - & Avustralya & 95.11 \\
4 & U07692 & Lucilia cuprina & - & Avustralya & 94.67 \\
5 & XM_023437798 & Lucilia cuprina & - & Avustralya & 91.56 \\
6 & XM_013261545 & Stomoxys calcitrans & - & ABD & 82.22 \\
7 & XM_013261544 & Stomoxys calcitrans & - & ABD & 82.22 \\
8 & XM_013261551 & Stomoxys calcitrans & - & ABD & 81.33 \\
9 & XM_013261549 & Stomoxys calcitrans & - & ABD & 80.09 \\
10 & XM_005183366 & Musca domestica & - & - & 79.02 \\
\hline
\end{tabular}

Klonlama reaksiyonları sonrasında oluşan koloniler görüntüleme cihazında (BioRad, ABD) görüntülenmiştir. Klonlamaların doğrulanması amacıyla rekombinant plazmitlerin DNA dizi analizi yapılmıştır. İzole edilen MT495795 Genbank numaralı L.sericata lusifensin izolatımız; Danimarka'da izole edilen HM243535 Genbank numaralı L.sericata izolatı ile \%98.92 benzerlik taşıdığı, Avustralya'da izole edilen XM_023451768 Genbank numaralı L.cuprina izolatı ile \%94.82 benzerlik taşıdığı tespit edilmiştir. MT495794 Genbank numaralı L.sericata izolatımızın ise Genbank'ta kayıtlı diğer benzer izolatlarla karşılaştırılma sonuçları gösterilmiştir (Tablo II).

Sonuçlar Geneious v10.0.7 (Biomatters, ABD) programına girilip dizi hizalamaları yapılmış ve bu iki gene ait konsensus dizileri ve kodladıkları amino asitler tespit edilmiştir (Şekil 1) (Şekil 2).

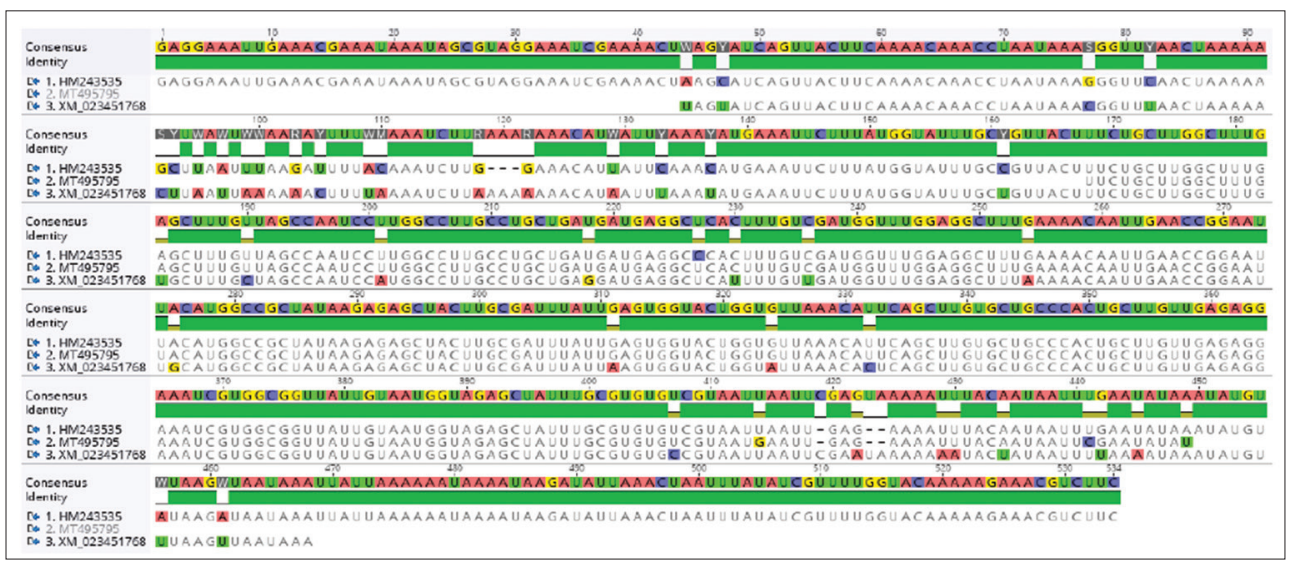

Şekil 1. L.sericata lusifensin nükleotit dizilerinin çoklu hizalamaları. 


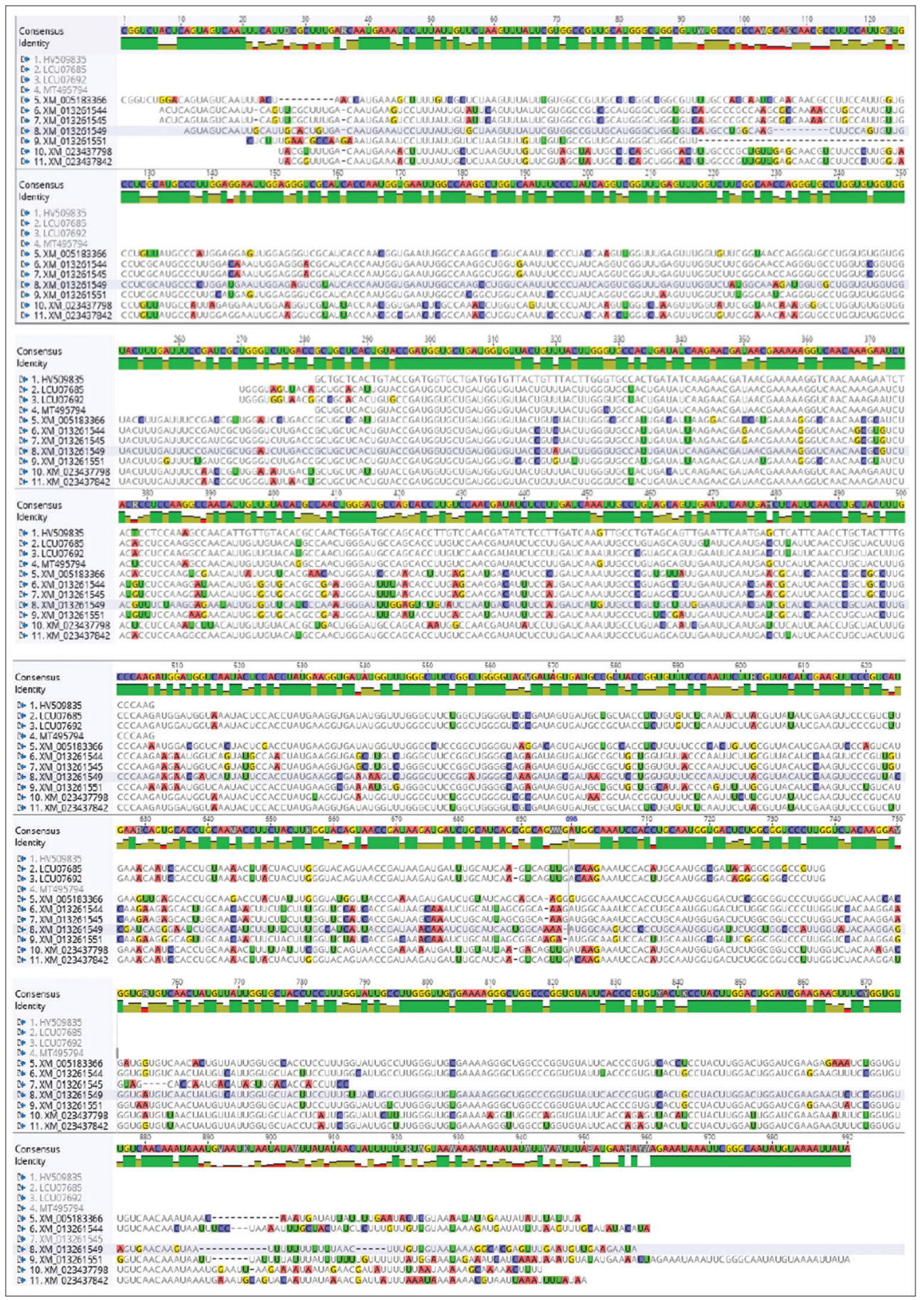

Şekil 2. L.sericata kimotripsin nükleotit dizilerinin çoklu hizalamaları. 


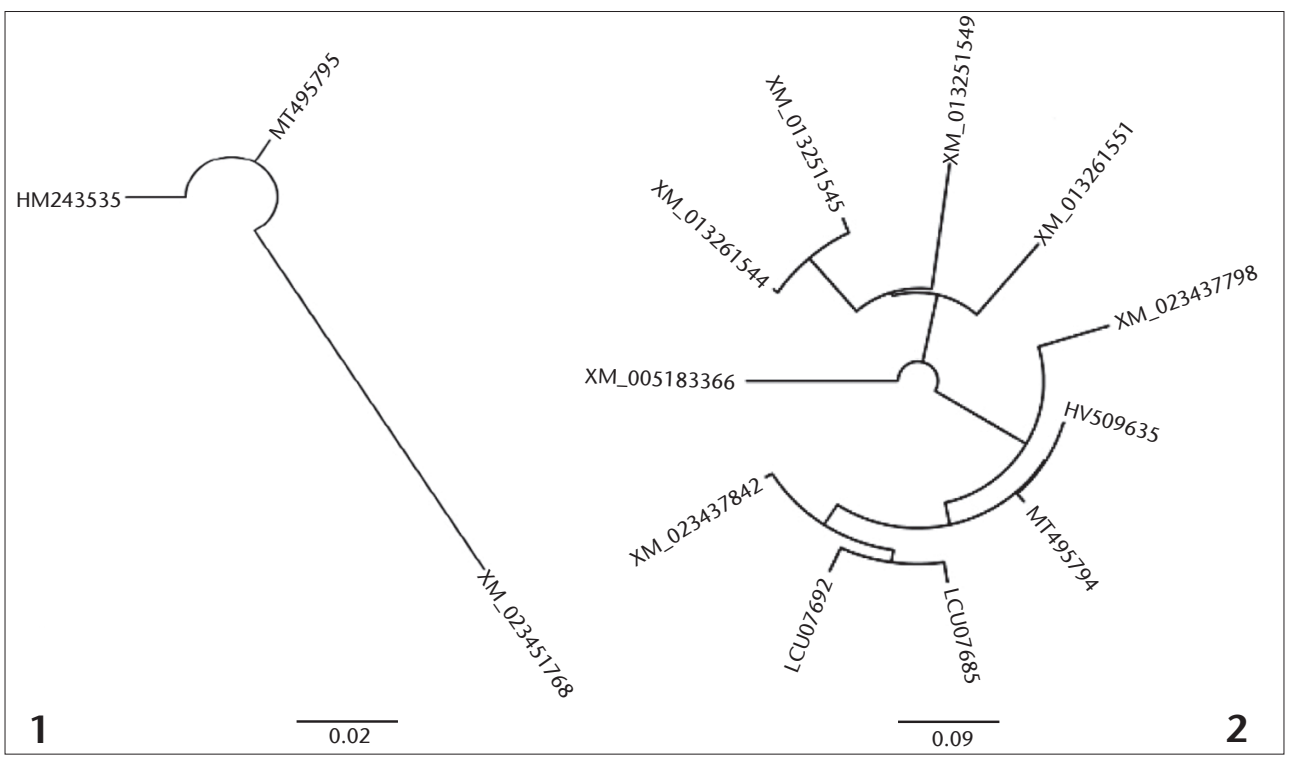

Şekil 3. L.sericata lusifensin geninin (1) (MT495795) ve kimotripsin geninin (MT495794) GenBank'a kayıtlı benzer dizilerle karşılaştırılmalı filogenetik analizi.

L.sericata lusifensin (MT495795), kimotripsin (MT495794) genlerinin Genbank'a kayıtları yapılmış ve Genbank'a girişi yapılan benzer izolatlarla karşılaştırılmıştır (Şekil 3).

L.sericata'nın lusifensin, kimotripsin proteinlerinin amino asit dizilimleri, antijenik bölgeleri ve üç boyutlu yapıları gösterilmiştir (Şekil 4).

\section{TARTIŞMA}

Lusifensin proteini, gram pozitif bakterilerde özellikle de Streptococcus suşları ve Staphylococcus suşları ile mücadelede oldukça etkilidir. Ek olarak, metisilin dirençli Staphylococcus aureus (MRSA) klinik izolatları üzerine de etkinliği gösterilmiştir ${ }^{8}$. Lusifensin proteini larvalarda son yıllarda hem salgılarında hem de iç organlarında tespit edilmiştir ${ }^{9}$. MDT uygulanırken larval sekresyon içerisindeki lusifensin proteini larvayı mikrobiyal floradan korumaktadır $^{10}$. 2011'de Micrococcus luteus ve Bacillus subtilis türlerine oldukça etkili savunma gösteren ilk kez in vitro sentezlenen lusifensin proteini bildirilmiştir. Bu sentetik peptitle ilgili S.aureus karşısında alt seviyede bir etki görülürken, E.coli karşısında ise hiçbir etki görülmemiştir. Çalışmaya göre böceklerdeki defensinlerin gram negatif bakterilerde gram pozitif bakterilere göre daha etkili oldukları sonucuna varılmıştır. Bu peptitlerin Candida albicans enfeksiyonuna karşılık alt seviyede antifungal etkinlik gösterebildiği insanlarda hemoglobinlere karşı da hemolitik olmadıkları bildirilmiştir ${ }^{11}$.

Biyoterapinin etkilediği mekanizmalar ile ekzojenik enzim merkezli debritman ürünler uyumlu bir birliktelik göstermektedir. Kurtçuklar, çeşitli insan analog molekülleri ile ek olarak ortaklaşa sindirim salgılarını kullanıp ölü dokuları parçalamaktadır. Aspartil metalo ve serin proteinaz gibi bileşenlerin fibroblast taşınmasına yardımcı hücre dışındaki mat- 


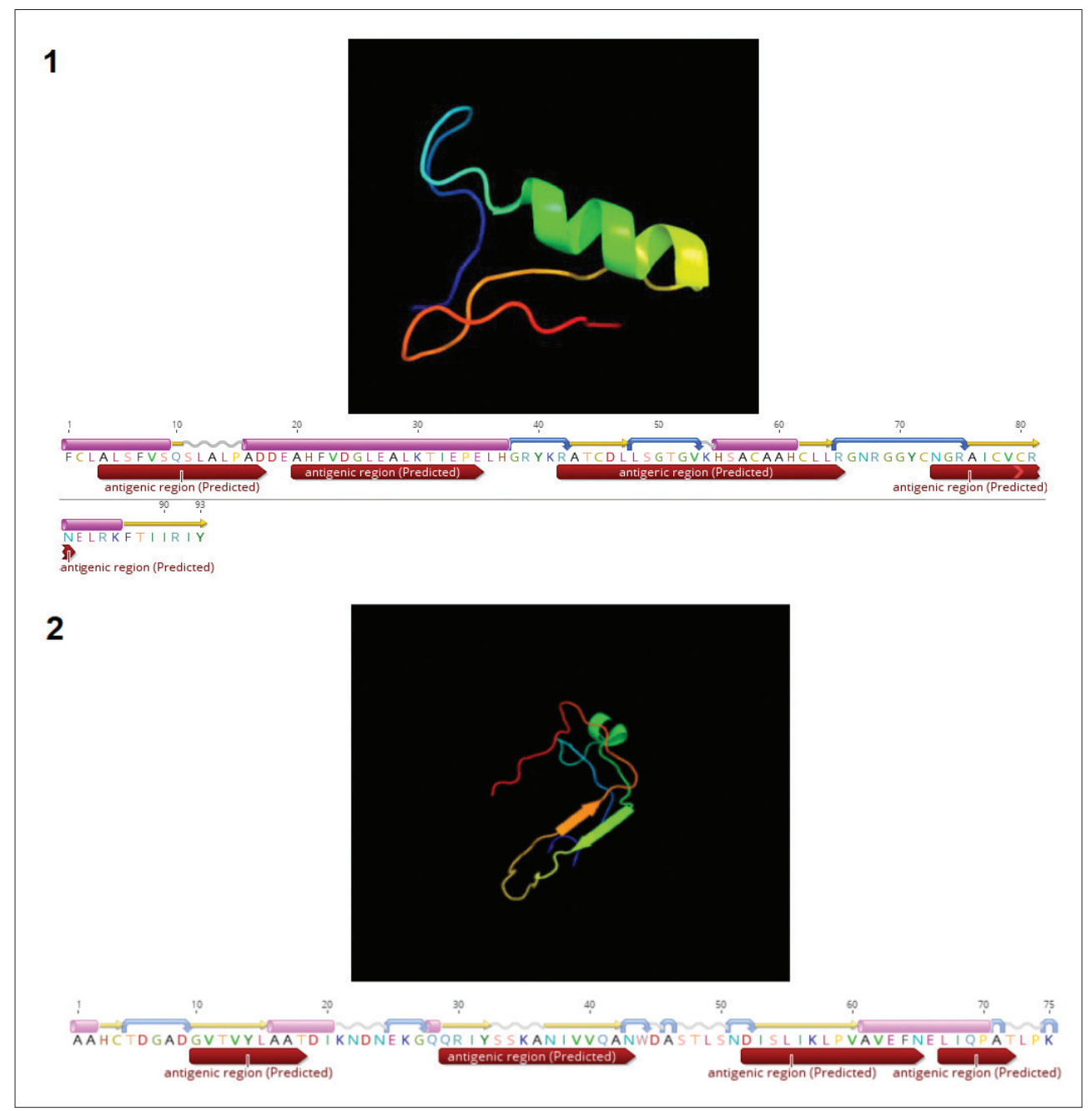

Şekil 4. L.sericata lusifensin proteininin (1) ve kimotripsin proteininin (2) üç boyutlu görünümü, aminoasit dizilimi ve antijenik bölgeleri.

riks bileşenleri çeşitliliğine azaltma yönünde yardımcı olduğu görülmüştür ${ }^{12}$. Kimotripsin proteini, memelilerdeki analoglarına kıyasla lezyonlarda daha etkili sonuçlar vermekte ve bu sonuçlarla birlikte önemli bir debritman molekülü olduğunu ispatlamaktadır ${ }^{4}$. Rekombinant olarak üretilen maggot kimotripsini insan kimotripsinine nazaran değişik inhibisyona sahipken ve lezyon yüzeyinde aktif kalıyorken, insan kimotripsini baskılanmaktadır. Oluşan bu durum kronik bacak ülserleri gibi olgularda maggot biyocerrahisi ile ilgili değişik mekanizmalar üzerinde çalışılmasına fırsat sunmaktadır ${ }^{13}$.

Maggot debritman tedavisi uzun yıllardan beri kronik yara tedavisinde başvurulan bir yöntem olmasına karşın tedavide kullanılan türlerin, yara tedavisinde önemli proteinleri 
ve genlerinin keşfi yakın zamanda gerçekleşmiştir. Özellikle çalışmamızda hedef aldığımız lusifensin ve kimotripsin proteinleri gibi birçok proteinin moleküler karakterizasyonları, rekombinant düzeyde ekspresyon çalışmaları da 21. yüzyılın ilk yarısından itibaren başlamıştır. Çalışmamızda; dizi sonuçları iki gen üzerinde incelenmiş ve sonuçlar GenBank veri tabanında mevcut izolatlarla karşılaştırılmıştır. Ayrıca, L.sericata lusifensin genine ait MT495795 Genbank numaralı izolatımız Türkiye Cumhuriyeti'nden bildirilen ilk veri olma özelliğini taşımaktadır. İzole edilen kimotripsin geninin İngiltere'de izole edilen HV509835 Genbank numaralı L. sericata izolatı ile \%99.55 benzerlik taşıdığı, Avustralya'da izole edilen XM_023437842 Genbank numaralı L.cuprina izolatı ile \%96.44 benzerlik taşıdığı, Avustralya'da izole edilen U07685 Genbank numaralı L.cuprina izolatı ile \%95.11 benzerlik taşıdığı, Avustralya'da izole edilen U07692 Genbank numaralı L.cuprina izolatı ile \%94.67 benzerlik taşıdığı, Avustralya'da izole edilen XM_023437798 Genbank numaralı L.cuprina izolatı ile \%91.56 benzerlik taşıdığı, Amerika Birleşik Devletleri'nde izole edilen XM_013261545 Genbank numaralı S.calcitrans izolatı ile \%82.22 benzerlik taşıdığı, ABD'de izole edilen XM_013261544 Genbank numaralı S.calcitrans izolatı ile \%82.22 benzerlik taşıdığı, ABD'de izole edilen XM_013261551 Genbank numaraIı S.calcitrans izolatı ile \%81.33 benzerlik taşıdığı, ABD'de izole edilen XM_013261549 Genbank numaralı S.calcitrans izolatı ile \%80.09 benzerlik taşıdığı ve XM_005183366 Genbank numaralı M.domestica izolatı ile \%79.02 benzerlik taşıdığı tespit edilmiştir. Ayrıca, L.sericata kimotripsin genine ait MT495794 Genbank numaralı izolatımız Türkiye Cumhuriyeti'nden bildirilen ilk veri olma özelliğini taşımaktadır.

Sonuç olarak bu çalışma ile Maggot debritman tedavisinde kullanılan L.sericata'nın lusifensin ve kimotripsin genlerinin moleküler karakterizasyonları yapılmış, Türkiye Cumhuriyeti'nden Genbank veritabanına L.sericata lusifensin ve kimotripsin genlerinin ilk kayıtları girilmiştir. Özellikle antibiyotik direnci ile birlikte farklı moleküllerin veya ajanların ortaya çıkarılması, moleküler karakterizasyonları, terapötik sistemlerde kullanılmaları adına uygun hale getirilmelerine ihtiyaç duyulmaktadır. Bu çalışma, bu tarz önemli bileşiklerin rekombinant olarak üretilmesi noktasında önümüzdeki yıllarda yapılacak benzer veya ileri seviyede çalışmalara kaynak olabilecek niteliktedir.

\section{ETIKK KURUL ONAYI}

Bu çalışma için etik kurul onayı gerekmemektedir.

\section{ÇIKAR ÇATIŞMASI}

Yazarlar bu makale ile ilgili herhangi bir çıkar çatışması bildirmemişlerdir.

\section{KAYNAKLAR}

1. Miman Ö, Saygı G. Temel Tıbbi Parazitoloji. 2018, İstanbul Tıp Kitabevi, İstanbul.

2. Rueda LC, Ortega LG, Segura NA, Acero VM, Bello F. Lucilia sericata strain from Colombia: Experimental colonization, life tables and evaluation of two artificial diets of the blowfly Lucilia sericata (Meigen) (Diptera: Calliphoridae), Bogota, Colombia strain. Biol Res 2010; 43(2): 197-203. 
3. Church JC. Larval intervention in the chronic wound. Eur Wound Manag Assoc 2001(1): 10-3.

4. Sherman RA, Hall MJ, Thomas S. Medicinal maggots: an ancient remedy for some contemporary afflictions. Annu Rev Entomol 2000; 45: 55-81.

5. Wilson M, Nigam Y, Jung W, Knight J, Pritchard D. The impacts of larval density and protease inhibition on feeding in medicinal larvae of the greenbottle fly Lucilia sericata. Med Vet Entomol 2016; 30: 1-7.

6. Bradley M, Cullum N, Sheldon T. The debridement of chronic wounds: a systematic review. Health Technol Assess 1999; 3(17): 1-78.

7. Mumcuoglu KY, Miller J, Mumcuoglu M, Friger M, Tarshis M. Destruction of bacteria in the digestive tract of the maggot of Lucilia sericata (Diptera: Calliphoridae). J Med Entomol 2001; 38(2): 161-6.

8. Andersen AS, Sandvang D, Schnorr KM, Kruse T, Neve S, Joergensen B, et al. A novel approach to the antimicrobial activity of maggot debridement therapy. J Antimicrob Chemother 2010; 65(8): 1646-54.

9. Kawabata T, Mitsui H, Yokota K, Ishino K, Oguma K, Sano S. Induction of antibacterial activity in larvae of the blowfly Lucilia sericata by an infected environment. Med Vet Entomol 2010; 24(4): 375-81.

10. Barnes KM, Gennard DE, Dixon RA. An assessment of the antibacterial activity in larval excretion/secretion of four species of insects recorded in association with corpses, using Lucilia sericata Meigen as the marker species. Bull Entomol Res 2010; 100(6): 635-40.

11. Cerovsky V, Bem R. Lucifensins, the insect defensins of biomedical importance: the story behind maggot therapy. Pharmaceuticals (Basel) 2014; 7(3): 251-64.

12. Nuesch R, Rahm G, Rudin W, Steffen I, Frei R, Rufli T, et al. Clustering of bloodstream infections during maggot debridement therapy using contaminated larvae of Protophormia terraenovae. Infection 2002; 30(5): 306-9.

13. Harris LG, Nigam Y, Sawyer J, Mack D, Pritchard DI. Lucilia sericata chymotrypsin disrupts protein adhesin-mediated staphylococcal biofilm formation. Appl Environ Microbiol 2013; 79(4): 1393-5. 